Al-Bayyinah: Journal of Islamic Law- ISSN: 1979-7486 (p); 2580-5088 (e) Volume VII Number 2, pp. 1- 12

\title{
ANALISIS PERHITUNGAN ZAKAT PROFESI DALAM SATUAN BRUTO DAN NETTO MENURUT HUKUM ISLAM
}

St. Rahmawati

(Dosen Tetap Hukum Islam IAIN Bone)

\section{Abstract}

Professional zakat is zakat issued from income, salary, services, wages or honorarium obtained by lawful means when it has arrived at the Nisab. The issuance of professional zakat is wiser and better if the community issues zakat from the total assets they get after the basic needs are met (net) in this case clothing, shelter, food, and basic necessities are no more than that. One fundamental mistake is to ignore the philosophy of Nisab and the occurrence of the determination of Nisab based on Gross (Gross) and Net (Net) income, which implies the uncertainty of professional zakat in addition to the practice of the syara order.

\section{Kata Kunci: Zakat profesi, bruto, neto, hukum Islam}

\section{A. Latar Belakang}

Zakat merupakan salah satu tiang agama dan termasuk ibadah. Fungsi zakat bukan hanya sebagai ibadah saja, pendapatan juga salah satunya adalah sebagai instrumen pemerataan. Namun fungsi zakat tesebut belum optimal di lembaga-lembaga pengumpul zakat, karena pengetahuan dan kesadaran masyarakat terhadap harta yang wajib dikeluarkan zakatnya masih terbatas pada sumber-sumber konvensional yang secara jelas dinyatakan dalam al-Qur'an dan hadis.

Berdasarkan hukum Islam, dalam harta kekayaan terkandung dua macam hak, yakni hak milik pribadi dan hak milik ummat atau hak sosial. Hak ummat itu merupakan amanat Allah yang dititipkan kepada tiap-tiap pemilik harta, 
yang harus ditunaikan menurut peraturan-peraturan yang telah ditetapkan oleh Allah dan Rasul-Nya. Adapun jenis harta yang wajib dikeluarkan zakatnya telah ditetapkan ketentuannya baik dalam al-Qur'an maupun as-Sunnah, yaitu berupa hasil bumi, hasil peternakan, barang yang diperdagangkan, emas dan perak. Klasifikasi ini tampaknya kurang memadai lagi dengan keadaan sekarang. Fiqh zakat yang sudah ada dan diajarkan di lembagalembaga pendidikan Islam, hampir seluruhnya hasil perumusan para ahli beberapa abad yang lalu yang banyak dipengaruhi oleh situasi dan kondisi setempat masa itu.

Perumusan zakat tersebut sudah tidak memadai lagi untuk mengatur pengelolaan zakat pada masyarakat saat ini yang memiliki berbagai usaha yang tidak ada pada masa lalu, disebabkan karena pada saat ini banyak profesi yang dapat menghasilkan uang cukup besar, dilakukan dengan cara yang mudah, dan dalam waktu yang relatif singkat, seperti pekerja profesional atau pekerja mandiri ${ }^{1}$ seperti pengacara, dokter, artis, dan lain-lain yang dalam waktu singkat dapat memperoleh penghasilan yang cukup besar. Oleh karenanya, permasalahan zakat sekarang ini memerlukan hukum-hukum baru yang mampu menjawab ketidakpastian dan keragu-raguan masyarakat. Karena jika permasalahan ini dikaitkan dengan pelaksanaan zakat yang sudah berjalan di masyarakat, maka terlihat adanya kesenjangan atau ketidakadilan antara petani yang banyak mencurahkan tenaga tetapi memiliki penghasilan kecil, namun tetap harus membayar zakat, dengan para pekerja profesional yang dalam waktu singkat dapat memperoleh hasil yang cukup besar tetapi tidak wajib zakat.

Dalam konteks Indonesia, melalui Undang-Undang Zakat No. 23 tahun 2011 tentang Pengelolaan zakat, ditetapkan tentang jenis-jenis harta yang wajib dizakati, salah satunya adalah zakat dari hasil pendapatan dan jasa (dalam pembicaraan selanjutnya disebut zakat profesi). Fatwa Ulama yang dihasilkan oleh Muktamar Internasional Pertama tentang zakat di Kuwait pada tanggal 29 Rajab 1404 H / 30 April 1984, juga disepakati tentang wajibnya membayar zakat dari hasil usaha

${ }^{1}$ Muhammad, Zakat Profesi: Wacana Pemikiran dalam Fiqih Kontemporer(Cet: I; Jakarta; Salemba Diniyah, 2002), h. 3. 
profesi apabila telah mencapai nishab. ${ }^{2}$ Meskipun UndangUndang dan kesepakatan ulama tersebut belum ditemui penjelasan tentang tata cara mengeluarkan zakatnya.

Bentuk zakat baru (setelah masa Nabi) tersebut merupakan sebuah langkah maju dari hasil ijtihad para ulama kontemporer, yang masih perlu pengkajian dan penelitian tentang keberadaan hukumnya dalam nash, baik al-Qur'an, Sunnah Rasul saw., ataupun ijtihad ulama terdahulu. Karena ada sebagian kaum modernis, seperti PERSIS dan Muhammadiyah, yang awalnya berpendapat tidak ada ijtihad, dalam hal ini penggunaan qiyas dalam urusan ibadat (zakat). ${ }^{3}$ Olehnya itu, perlu adanya Analisis Perhitugan Zakat Profesi Dalam Pemikiran Fikih Kontemporer.

\section{B. Rumusan Masalah}

Adapun rumusan masalah yang diajukan dalam penelitian ini adalah:

1. Apa yang dimaksud dengan zakat profesi?

2. Apa pentingnya perhitungan zakat profesi dengan nilai bruto dan netto?

\section{Tujuan dan Kegunaan Penelitian}

Adapun tujuan penelitian ini adalah untuk mengetahui pengertian zakat profesi dan pentingnya perhitungan zakat profesi dalam nilai bruto dan netto. Sedangkan kegunaannya adalah sebagai informasi dan pengetahuan dalam hal perhitungan zakat profesi bgi penulis dan bagi masyarakat sebagai pengetahuan agar dalam pengeluaran zakat profesi dapat ditunaikan sesuai dengan syarat-syarat yang ditentukan oleh syariat.

${ }^{2}$ Didin Hafidhuddin, Zakat dalam Perekonomian Modern (Jakarta: Gema Insani Pers, 2002), h. 95.

${ }^{3}$ Jalaludin Rahmat, Islam Aktual (Cet: VII; Bandung: Mizan, 1994), h. 148 . 


\section{Metodologi Penelitian}

Penelitian ini berbentuk penelitian hukum/normatif. Jenis penelitian ini juga biasa disebut sebagai penelitian hukum doktriner atau penelitian perpustakaan. Dalam penelitian ini, peneliti menggunakan analisis deskriptif. Adapun pendekatan yang digunakan, yakni pendekatan teologis dan pendekatan yuridis-formal. Pembahasan penelitian ini berdasar pada cara pengambilan data berupa kutipan langsung dan kutipan tidak langsung, kemudian dianalisis menggunakan teknik analisis deduktif.

\section{E. Hasil Pembahasan}

1. Ketentuan Dasar Zakat

\section{a. Pengertian Zakat dan Dasar Hukum Zakat}

Secara bahasa, zakat berarti al-numuwwu (tumbuh) dan al-ziyadah (bertambah). Jika diucapkan, zaka al-zar, artinya tanaman itu tumbuh dan bertambah. Jika diucapkan zakat al-nafaqah, artinya nafkah tumbuh dan berkembang jika diberkati. Kata ini juga sering dikemukakan untuk makna taharah (suci). ${ }^{4}$ Sementara, dalam buku Al Mughni karangan ibnu qudamah $\mathrm{Abu}$ Muhammad bin $\mathrm{Abu}$ Qutaibah mengatakan: zakat berasal dari kata zakat (bersih), namaa (tumbuh dan berkembang) dan ziadah pengembangan harta. ${ }^{5}$

Zakat menurut syara adalah sejumlah harta tertentu yang diwajibkan oleh Allah swt., untuk diberikan kepada orang yang berhak menerima zakat (mustahiq) yang disebutkan dalam al-Qur'an/9: 60. Selain itu, bisa juga berarti sejumlah harta tertentu dari harta tertentu yang diberikan kepada orang yang yang berhak menerimanya dengan syarat-syarat tertentu. ${ }^{6}$

Sementara, dalam UU No. 23 Tahun 2011 pasal 1 ayat (2) juga dijelaskan, zakat adalah harta yang wajib

${ }^{4}$ Wahbah Al-Zuhayly, Zakat Kajian Berbagai Mashab (Cet. 1; Bandung, PT. Remaja Rosdakarya, 1997), h. 82.

${ }^{5}$ Ibnu qudamah, Al Mughni, alih bahasa oleh Amir Hamzah (Cet. III; Jakarta, Pustaka Azzam, 2007), h. 433.

${ }^{6}$ Hikmat Kurnia dan A. Hidayat, Panduan Pintar zakat (Cet. 1; Jakarta: Qultum Media, 2008),, h. 3. 
dikeluarkan oleh seorang muslim atau badan usaha untuk diberikan kepada yang berhak menerimanya sesuai dengan syariat Islam.

Zakat, hukumnya fardhu ain bagi setiap muslim apabila telah memenuhi syarat-syarat yang telah ditentukan oleh syari'at, dan merupakan kewajiban yang disepakati oleh umat Islam dengan berdasarkan dalil alQur'an, hadits, dan ijma. ${ }^{8}$

Allah berfirman dalam QS. al-Baqarah/2: 267:

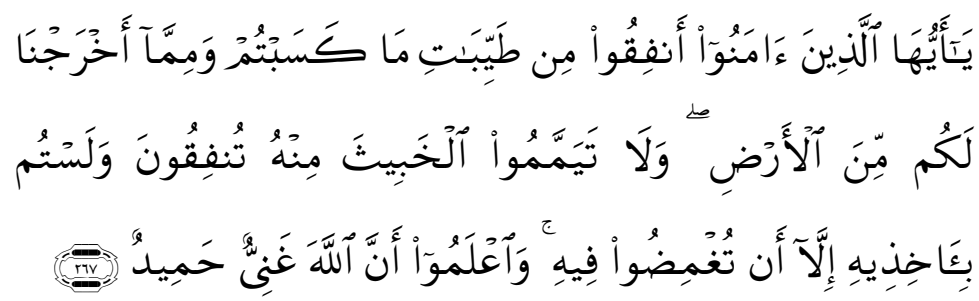

Terjemahnya:

Hai orang-orang yang beriman, nafkahkanlah (di jalan Allah) sebagian dari hasil usahamu yang baik-baik dan sebagian dari apa yang kami keluarkan dari bumi untuk kamu. dan janganlah kamu memilih yang buruk-buruk lalu kamu menafkahkan daripadanya, padahal kamu sendiri tidak mau mengambilnya melainkan dengan memincingkan mata terhadapnya. Ketahuilah, bahwa Allah Maha Kaya lagi Maha Terpuji.

Kewajiban nenunaikan zakat juga terdapat dalam hadis Nabi saw., yang diriwayatkan oleh al- Bukhari:

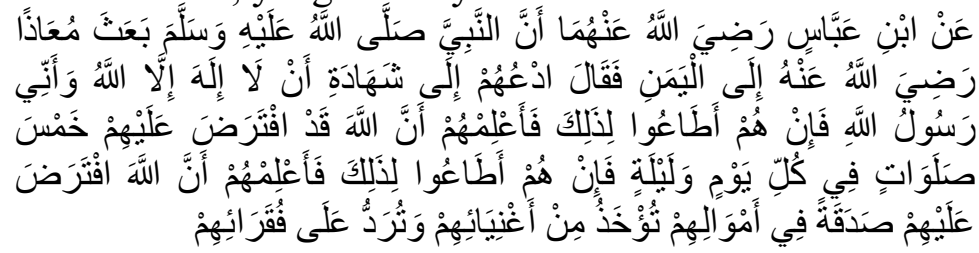

${ }^{7}$ Undang-Undang Republik Indonesia Nomor 23 Tahun 2011 Tentang Pengelolaan Zakat.

${ }^{8}$ Hikmat Kurnia dan A. Hidayat, Panduan Pintar Zakat, h. 4.

${ }^{9}$ Kementerian Agama RI, Al-Qur'an Terjemah (Cet. II; Jakarta: Kelompok Gema Insani Press, 2002), h. 67. 
Artinya:

Dari Ibnu 'Abbas radliallahu 'anhuma bahwa ketika Nabi Shallallahu'alaihiwasallam mengutus Mu'adz radliallahu 'anhu ke negeri Yaman, Beliau berkata,: "Ajaklah mereka kepada syahadah (persaksian) tidak ada ilah yang berhak disembah kecuali Allah dan bahwa aku adalah utusan Allah. Jika mereka telah mentaatinya, maka beritahukanlah bahwa Allah mewajibkan atas mereka shalat lima waktu sehari semalam. Dan jika mereka telah mena'atinya, maka beritahukanlah bahwa Allah telah mewajibkan atas mereka shadaqah (zakat) dari harta mereka yang diambil dari orang-orang kaya mereka dan diberikan kepada orang-orang faqir mereka". ${ }^{10}$

Dilihat dari ayat dan hadis tersebut menunjukkan eksistensi kewajiban menunaikan zakat sama halnya dengan kewajiban melaksanakan sholat. Karena sholat dan zakat tidak dapat dipisahkan.

\section{b. Syarat-syarat Zakat Mal dan Harta-harta Wajib Zakat}

Adapun syarat-syarat wajib zakat, yaitu milik sempurna, berkembang secara riil atau estimasi, sampai nisab, melebihi kebutuhan pokok, tidak terjadi zakat ganda, dan cukup haul (genap satu tahun).

Adapun harta yang wajib dizakati, yakni zakat hewan ternak, zakat emas dan perak, zakat perdagangan, zakat hasil pertanian, zakat barang tambang (ma'din), dan barang temuan (rikaz). Harta wajib zakat ini merupakan priodenisasi pada masa Rasulullah saw, dan Khulafa Rasyidin yang dipandang bukan harta berkembang. Jika dahulu banyak harta-harta yang berkembang, maka pada waktu sekarang ini, malah merupakan sumber penghasilan yang mendatangkan kekayaan. ${ }^{11}$ Dengan substansi alNama, hasbi menunjukkan sejumlah harta wajib zakat di

${ }^{10}$ Muhammad Nashiruddin al-Albani, Ringkasan Shahih al-Bukhari (Cet. 1; Jakarta:Pustaka as-Sunnah, 2007), h. 836-837.

11 A. Sarjan, Pembaharuan Pemikiran Fikih Hasbi Ash-Shiddieqy (Cet. 1; Jakarta: Yameka Muslim Indonesia-Indonesia Muslim, 2007), h. 95. 
zaman sekarang seperti zakat industri rumah atau investasi, zakat uang kertas ${ }^{12}$ dan zakat profesi.

\section{Zakat Profesi}

\section{a. Pengertian Zakat Profesi}

Kata profesi berasal dari bahasa inggris "Profession" yang berarti pekerjaan. Dalam terminologi Arab dikenal dengan istilah al- mihn. Kalimat ini merupakan bentuk jama' dari al-mihn yang berarti pekerjaan atau pelayanan.Profesi secara istilah berarti suatu pekerjaan yang membutuhkan pengetahuan, keahlian, dan kepintaran.Yusuf al-Qardhawi mengemukakan bahwa profesi adalah pekerjaan atau usaha yang menghasilkan uang atau kekayaan baik pekerjaan itu dilakukan sendiri tanpa bergantung kepada orang lain, maupun dengan bergantung kepada orang lain, seperti pemerintah, perusahaan swasta, maupun perorangan dengan memperoleh upah, gaji, atau honorarium. ${ }^{13}$ Engan demikian, ada 4 inti dari profesi, yaitu jenis usahanya halal, dapat uang banyak, cara yang mudah untuk mendapatkan, dan keahlian tertentu.

Ada beberapa profesi yang dapat menjadi sumber zakat, antara lain:

1. Profesi dokter yang dapat dikategorikan sebagai the medical profession;

2. Profesi pekerja tekhnik (insinyur) yang dapat dikategorikan sebagai the engineering profession;

3. Profesi guru, dosen, guru besar atau tenaga pendidik yang dapat dikategorikan sebagai the teaching profession;

4. Profesi advokat (pengacara), konsultan, wartawan, pegawai dan sebagainya. ${ }^{14}$

\footnotetext{
${ }^{12}$ A. Sarjan, Pembaharuan Pemikiran Fikih Hasbi Ash-Shiddieqy, h.
} 98.

${ }^{13}$ Yusuf al-Qardhawi, Fiqh al-Zakah, Juz I (t.cet; Beirut : Muassasah alRisalah, 1994), h. 25.

${ }^{14}$ Mahjuddin, Masailul Fiqhiyah (Cet. VI; Jakarta: Kalam Mulia, 2007), h. 280. 


\section{b. Perhitungan Nisab Zakat Profesi dengan Nilai Bruto dan Netto}

Para imam mazhab tidak sependapat tentang wajibnya zakat penghasilan. Imam Syafi'i tidak mewajibkan zakat walaupun telah memenuhi satu nisab dan mencapai waktu setahun untuk mengeluarkan zakat harta penghasilan, demikian pula Imam Malik tidak mewajibkan mengeluarkan zakat harta penghasilan setelah mencapai masa setahun dengan syarat mencapai nisab.Adapun Imam Abu Hanifah mempersyaratkan setahun penuh pemilikan harta penghasilan, kecuali apabila harta tersebut sudah ada satu nisab, maka zakat harta penghasilan itu harus dikeluarkan walaupun belum ada satu tahun, jadi dikeluarkan pada permulaan tahun.Sedangkan dalam literatur tidak ditemukan pendapat Imam Hanbali tentang masalah zakat profesi. ${ }^{15}$

Dalam perhitungan nisab zakat profesi terdapat beberapa kemungkinan kesimpulan dalam menentukan nisab, kadar dan waktu pengeluaran zakat profesi. Hal ini sangat tergantung pada qiyas (analogi) yang dilakukan. Oleh karena itu masalah zakat profesi tetap bersifat ijtihadi yang menjadi garapan para fuqah atau ulama kontemporer yang dapat digolongkan paling sedikit tiga pendapat mengenai hal ini.

1. Syaikh Muhammad al-Ghazali menganalogikan zakat profesi dengan zakat hasil pertanian, baik dalam nisab maupun besarnya zakat yang wajib dikeluarkannya. Besar zakatnya adalah $10 \%$ atau $5 \%$ dari hasil yang diterima tanpa terlebih dahulu dipotong kebutuhan pokok, sama dengan petani ketika mengeluarkan zakat hasil panennya. Perbedaan mengeluarkan zakat $10 \%$ atau $5 \%$ karena perbedaan biaya menggunakan alat-alat mekanik atau tidak menggunakannya.

2. Mazhab Imamiyah (Mazhab Ahlil Bait) berpendapat bahwa zakat profesi itu $20 \%$ dari hasil pendapatan bersih, sama seperti dalam laba perdagangan serta setiap hasil pendapatan lainnya.

${ }^{15}$ Al-Zarqany, Syarh al-Zarqany ala Muwatta"al-Imam Maliki (Juz II, Tk: Dar al-Fikr,tt), h. 568.

${ }^{16}$ Al-Zarqany, Syarah al-Zarqany II, h. 97. 
3. Yusuf al-Qardhawy menyatakan, bahwa besarnya zakat profesi disamakan dengan uang atau perdagangan, yaitu 2,5\% dari hasil perdapatan; beliau berkata: "benar, bahwa nikmat Allah dalam hasil tanaman dan buahbuahan lebih jelas dan mensyukurinya lebih wajib, namun demikian tidak berarti bahwa salah satu pendapatan tersebut tegas wajib zakat sedangkan yang satu lagi tidak. Perbedaannya cukup dengan bahwa pembuat syarie'at mewajibkan zakat hasil tanah sebesar sepersepuluh atau seperdua puluh sedangkan pada harta penghasilan berupa uang atau yang senilai dengan uang, sebanyak seperempat puluh. ${ }^{17}$

Ulama yang menganalogikan zakat profesi kepada zakat perdagangan, maka nisab, kadar, dan waktu pengeluarannya sama dengannya dan sama pula dengan zakat emas dan perak. Nisabnya senilai 85 gram emas, kadar zakatnya $2,5 \%$ dan waktu pengeluarannya setahun sekali, setelah dikurangi kebutuhan pokok. ${ }^{18}$

Pembayaran zakat profesi jika diqiyaskan pada emas dan perak dapat ditempuh dengan dua cara, yaitu diakhir tahun (bulan ke 12 zulhijjah) dan atau tiap bulan. Cara yang diperkenalkan oleh Musthafa Yakuf dengan rumusnya $12 \mathrm{x}$ total pendapatan : $12 .{ }^{19}$

Jika dianalogikan pada zakat pertanian, baik nisab maupun kadar zakatnya. Nisab zakat profesi setara dengan $653 \mathrm{~kg}$ beras dan kadar zakat 5\% atau 10\% (tergantung kadar keletihan yang bersangkutan) dan dikeluarkan setiap menerima gaji, tidak perlu menunggu batas waktu setahun. ${ }^{20}$ Dengan demikian, apabila dihitung berdasarkan kondisi pasar dengan nilai uang terhadap beras, maka dengan mengamati harga beras di pasaran adalah Rp. 6. 500,-, maka nisab beras dalam nilai uang adalah Rp. 4. 244. 500,-.

${ }^{17}$ Anik Nur Latifah, Kedudukan Hukum Zakat Profesi Dan Pembagiannya, (t.d.), h. 16.

${ }^{18}$ Didin Hafidhuddin, Zakat dalam Perekonomian Modern (Cet. I; Jakarta: Gema Insani Press, 2002), h. 96.

${ }^{19}$ A. Sarjan, Fikih Zakat dalam Kajian Normatif, Kontekstual dan Kontemporer ( Cet. I; Yogyakarta: Prudent Media, 2013) h. 96-97.

${ }^{20}$ Hikmat Kurnia dan A. Hidayat, Panduan Pintar Zakat, h. 251. 
Berdasarkan hitungan tersebut, maka gaji seorang profesional seperti Pegawai, karyawan, Dosen dan lain-lain yang jumlahnya sebesar Rp. 4. 244. 500,-. atau lebih perbulan dikategorikan telah mencapai nisab zakat. Dengan demikian, yang bersangkutan wajib membayar zakat setiap bulan sesuai penghasilan/gaji dari profesi yang dijalankannya. Pendapat ini dikemukakan oleh Musthofa Samiun dan Hasanuddin. ${ }^{21}$

Menurut Yusuf Qardhawi dalam perhitungan zakat profesi dibedakan menurut dua cara, yaitu:

1. Secara langsung, yaitu zakat dihitung 2,5\% dari penghasilan kotor secara langsung, baik dibayarkan bulanan atau tahunan. Contohnya, seseorang dengan penghasilan Rp 3.000.000 tiap bulannya, maka diwajibkan membayar zakat sebesar 2,5\%xRp 3.000.000 = Rp 75.000/bulan atau $\mathrm{Rp} 900.000 /$ tahun.

2. Setelah dipotong kebutuhan pokok, yaitu zakat dihitung 2,5\% dari gaji setelah dipotong dengan kebutuhan pokok. Contoh: seseorang dengan penghasilan Rp 1.500.000,dengan pengeluaran untuk kebutuhan pokok Rp 1.000.000 tiap bulannya, maka wajib membayar zakat sebesar: $2,5 \% \mathrm{x}$ $(\operatorname{Rp} 1.500 .000-\operatorname{Rp} 1.000 .000)=\operatorname{Rp} 12.500 /$ bulan atau Rp. 150.000/tahun.

\section{F. Penutup}

Simpulan dalam penulisan ini, sebagai berikut:

1. Zakat profesi adalah zakat yang dikeluarkan dari penghasilan, gaji, jasa, upah atau honorarium yang diperoleh dengan cara halal apabila telah sampai nisabnya. Zakat profesi merupakan zakat yang relatif baru yang tidak ada secara jelas nash-nya dalam alQur'an dan hadis. Semua macam penghasilan (gaji, honorium) terkena wajib zakat berdasarkan ketentuan surah al-Baqarah ayat 267 yang mengandung pengertian umum, asal penghasilan tersebut telah mencapai nisab dan melebihi ketentuan pokok hidupnya dan

${ }^{21}$ Noor Aflah, Arsitektur Zakat Indonesia (Cet. 1 ; Jakarta : UI Press, 2009), h. 115. 
keluarganya yang berupa sandang, pangan yang diperoleh dengan cara baik-baik.

2. Dalam menentukan apakah ketika menghitung zakat profesi ini, gaji dipotong kebutuhan hidup dan piutang (netto) terlebih dahulu ataukah tidak (bruto). Dalam hal ini, penulis berpendapat bahwa membayar zakat profesi setelah terpenuhi segala kebutuhan pokoknya lebih rasional karena si muzakki benar-benar mapan/kaya sesuai syariat yang ditetapkan oleh syara.'

\section{G. Daftar Pustaka}

Aflah, Noor. Arsitektur Zakat Indonesia. Cet. 1 ; Jakarta : UI Press, 2009.

al-Albani, Muhammad Nashiruddin. Ringkasan Shahih alBukhari. Cet. 1; Jakarta:Pustaka as-Sunnah, 2007.

Hafidhuddin, Didin. Zakat dalam Perekonomian Modern. Cet. I; Jakarta: Gema Insani Press, 2002.

Kementerian Agama RI. Al-Qur'an Terjemah. Cet. II; Jakarta: Kelompok Gema Insani Press, 2002.

Kurnia, Hikmat dan A. Hidayat. Panduan Pintar Zakat. Cet. 1; Jakarta: Qultum Media, 2008.

Latifah, Anik Nur. Kedudukan Hukum Zakat Profesi Dan Pembagiannya. (t.d.).

Mahjuddin. Masailul Fiqhiyah. Cet. VI; Jakarta: Kalam Mulia, 2007.

Muhammad. Zakat Profesi: Wacana Pemikiran dalam Fiqih Kontemporer. Cet: I; Jakarta; Salemba Diniyah, 2002. al-Qardhawi, Yusuf. Fiqh al-Zakah. Juz I. t.cet; Beirut : Muassasah al-Risalah, 1994.

Qudamah, Ibnu. Al Mughni. Alih bahasa oleh Amir Hamzah. Cet. III; Jakarta, Pustaka Azzam, 2007.

Rahmat, Jalaludin. Islam Aktual. Cet: VII; Bandung: Mizan, 1994.

Sarjan, A. Fikih Zakat dalam Kajian Normatif, Kontekstual dan Kontemporer. Cet. I; Yogyakarta: Prudent Media, 2013. 
—. Pembaharuan Pemikiran Fikih Hasbi Ash-Shiddieqy. Cet. 1; Jakarta: Yameka Muslim Indonesia-Indonesia Muslim, 2007.

Undang-Undang Republik Indonesia Nomor 23 Tahun 2011 Tentang Pengelolaan Zakat.

al-Zarqany. Syarh al-Zarqany ala Muwatta"al-Imam Maliki. Juz II, Tk: Dar al-Fikr,tt.

al-Zuhayly, Wahbah. Zakat Kajian Berbagai Mashab. Cet. 1; Bandung, PT. Remaja Rosdakarya, 1997. 